To Cite: Elmastas A, Umaz A, Aydin F, 2021. Investigation of Changes Against Time in the Artificial Gastric Liquid Medium of Pesticide Active Substances. Journal of the Institute of Science and Technology, 11(2): 1270-1278.

Investigation of Changes Against Time in the Artificial Gastric Liquid Medium of Pesticide Active Substances

Ayhan ELMASTAS ${ }^{1}$, Adil UMAZ2*, Firat AYDIN ${ }^{3}$

\title{
Investigation of Changes Against Time in the Artificial Gastric Liquid Medium of Pesticide Active Substances
}

\begin{abstract}
In this study, grown tomato samples were examined changes of pesticide active substances by two different methods in the artificial gastric liquid (AGL) medium prepared. In the first method, Trifloxystrobin and Imidacloprid pesticide active substances were sprayed on the tomato samples before the harvest period. Time-dependent change of the active substance of Trifloxystrobin; although initially $83.17 \mathrm{ng} \mathrm{g}^{-1}$, it was determined as $24.71 \mathrm{ng} \mathrm{g}-1 \mathrm{in} 240 \mathrm{~min}$. The concentration of this active substance was determined that decreased with time and the $\%$ change was 70.29 . While Imidacloprid active substance initially was $10.20 \mathrm{ng}$ g-1, it was determined as $10.32 \mathrm{ng}$ g-1 at $240 \mathrm{~min}$. It was determined that this active substance did not change between the first and the last concentration depending on the time. In the second method, 75 pesticide active substances were spiked to the tomato sample and the time-dependent change in the AGL medium was examined. The concentration of 10 active substances that above $70 \%$ of the change rate was determined that there was a statistical decrease depending on the time \% changes in the range between 0-240 min. The concentration of 30 active substances in below $70 \%$ of the change rate was determined that did not a statistical decrease as depending on time. however, $\%$ changes were observed that there was a certain thought at different rates between the first and the last concentration after $240 \mathrm{~min}$. The last 15 active substances $240 \mathrm{~min}$ concentrations were determined that increased of $\%$ changes compared to 0 min.
\end{abstract}

Keywords: Pesticide, tomato, LC-MS/MS, GC-MS/MS, AGL medium

\footnotetext{
${ }^{1}$ Ayhan ELMASTAS (Orcid ID: 0000-0002-9208-9852), Ministry of Agriculture and Forestry, Diyarbakir Food Control Laboratory, Diyarbakır, Turkey

${ }^{2}$ Adil UMAZ (Orcid ID: 0000-0003-2438-5454), Mardin Artuklu University, Vocational School of Health Services, Medical Laboratory Department, Mardin, Turkey,

${ }^{3}$ Frrat AYDIN (Orcid ID: 0000-0002-0868-2769), Dicle University, Science Faculty, Chemistry Department, Diyarbakır, Turkey,

*Corresponding Author: Adil UMAZ, e-mail: adilumaz@gmail.com

This study was produced from Ayhan ELMASTAS's PhD thesis.
} 


\section{INTRODUCTION}

Fruits and vegetables create an important part of our daily diet. In order for the fruits and vegetables consumed to be useful, they should not contain any pesticide residues or are below the specified limits (Elmastas, 2018). Pesticides are known as agrochemicals used to, prevent, spray, or destroy harmful organisms and substances, growth, and development of the plant (Wu et al., 2019). Pesticides according to their chemical structures and functional groups are classified into various forms including organochlorine, organophosphorus, and carbamate. The most well-known among organochlorinated pesticides are Chlordane, Heptachlor and, Dichlorodiphenyltrichloroethane (DDT). The most known organophosphated pesticides are Chlorpyrifos, Diazinon, Malathion, and, Parathion. The most commonly known carbamate pesticides are Aldicarb, Carbaryl, Carbofuran. Also, some pesticides used as insecticides are Acetamiprid, Chlorpyrifos, Dieldrin, Heptenophos, Imidacloprid, Malathion, and Pirimicarb. Some pesticides used as protective fungicides are Azoxystrobin, Boscalid, Difenoconazole, Trifloxystrobin, and Tebuconazole (Elmastas, 2018).

The history of pesticides known that used sulfur dust for insect controls by people in ancient Mesopotamia around $2500 \mathrm{BC}$. Although the use of pesticides can improve the quality and quantity of crops, pesticide residues in crops are generally harmful to humans. For this reason, many international organizations have regulated the maximum residue limits (MRL) in crops (Wu et al., 2019). These organizations are WHO, EC 2005, USDA, CODEX, CAC, HSE, and EFSA (Elmastas, 2018; Algharibeh and AlFararjeh, 2019; Jara and Winter, 2019). In our country, MRL is determined by the Ministry of Food, Agriculture, and Livestock (Elmastaş, 2018). MRL value of pesticides commonly used in the European Union (EU) agricultural products is determined as $0.01 \mathrm{mg} \mathrm{kg}^{-1}$ (Wu et al., 2019).

Despite benefits in agricultural areas of pesticides, it is known that it has had dangerous effects recently (Wei et al., 2018). In the release to nature of pesticides and consumption of food products contaminated with pesticides various health problems such as headaches, flu, skin rash, blurred vision, especially neurological and behavioral disorders in children, serious poisoning, blindness, genetic mutations, various types of cancer, birth defects, reproductive disorders, genotoxicity, carcinogenesis, cardiovascular diseases, endocrinological disorders in humans and animals, and even causes death (Arias et al., 2013; Hou et al., 2018; Calvo et al., 2019; Ersoy et al., 2019; Farajzadeh et al., 2019). Pesticides are not only toxic to the environment and human health. They are also known phytotoxic because of reactive oxygen species (ROS), lipid peroxidation, protein damage, and cause oxidative stress through DNA breaks (Hou et al., 2018). One of the most important negative effects of pesticides gives the longterm potential damage to the health of practitioners and other staff exposed to pesticides, as well as varying acute-grade injury. Studies estimate that 2-3 people are poisoned by pesticides every minute, and about 20.000 agricultural workers die from pesticide poisoning every year (An et al., 2018).

Various analysis techniques are used to identify pesticide residues (Song et al., 2019). Some of those are gas chromatography (GC), liquid chromatography (LC) (Farajzadeh et al., 2019), gas chromatography-mass spectrometry (GC-MS), liquid chromatography-mass (LC-MS) (Song et al., 2019), liquid chromatography-tandem mass spectrometry (LC-MS/MS) (Algharibeh and AlFararjeh, 2019), GC-MS/MS (Lehotay, 2019), ultraviolet (UV) and fluorescent (FLD) detectors equipped with LC (Kapsi et al., 2019).

In this study, the time-dependent change of pesticide active substances in two different medium conditions in the AGL medium prepared grown tomato samples was examined. In the first medium, Trifloxystrobin and Imidacloprid active substances were sprayed on tomato samples before harvest. The time-dependent changes in the prepared AGL medium of these two active substances in the tomato 
samples were examined. In the 2nd medium, some pesticide active substances were spiked to the tomato sample. The behaviors against time in the AGL of pesticide active substance spiked on tomato samples were investigated. In the literature, there is no information about monitoring the behavior of pesticide active substances in AGL. Thanks to this study, the knowledge of how the pesticide active substances change in the AGL medium will offer to contribute to the literature. Again, thanks to this study, it will be a guide in terms of working and evaluation in different artificial medium liquids.

\section{MATERIAL AND METHODS}

\section{Herbal Material}

Tomato sample was grown in the Research and Application field of Dicle University Faculty of Agriculture, Department of Horticulture. Tomato samples grown before harvesting time were done spraying process with Trifloxystrobin and Imidacloprid active substance and used in experimental studies.

\section{Chemicals and Reagents}

Pesticide standards (Dr. Ehrenstorfer GmbH), Pepsin, and Hydrochloric acid (Sigma Aldrich, Germany) were provided commercially. Preparation of AGL; 6 g Pepsin 1\% serum physiological solution taken and $4 \mathrm{M} 2.5 \% \mathrm{HCl}$ solution added on it. Then the final volume of the mixture was completed to $1000 \mathrm{ml}$. The $\mathrm{pH}$ of the AGL medium was adjusted to 1.2 (Galia et al., 1998).

\section{Extraction of Samples}

The extraction of the samples was done according to the AOAC 2007.01 (International Official Methods of Analysis) method. Extraction procedures were carried out as follows.

$15 \mathrm{~g}$ of tomato sample was weighed and homogenized with the help of a homogenizer. The obtained $15 \mathrm{~g}$ of the homogeneous mixture was taken into a $50 \mathrm{~mL}$ centrifuge tube and $15 \mathrm{~mL}$ of acetonitrile solution containing $1 \%$ acetic acid on it was added. Later the mix 1 min mixed with the vortex. Then, the salt mixture prepared from a mixture of $6 \mathrm{~g}$ magnesium sulfate and $1.5 \mathrm{~g}$ sodium acetate was added to the tube and the mixture was shaken for $1 \mathrm{~min}$ with the vortex. The mixture was then centrifuged at $4000 \mathrm{rpm}$ for $5 \mathrm{~min}$. Then, $8 \mathrm{~mL}$ of the upper phase was taken and placed in the centrifuge tube, and the salt mixture prepared from a mixture of $0.4 \mathrm{~g}$ primer amine and $1.2 \mathrm{~g}$ magnesium sulfate was added to the tube. The mixture was shaken by the vortex for $1 \mathrm{~min}$ and centrifuged at $4000 \mathrm{rpm}$ for $5 \mathrm{~min}$. Then, the upper phase was taken and filtered through a $0.45 \mu \mathrm{m}$ filter and taken into the vial.

\section{Pesticide Active Substances in Tomato Sample}

A total of 75 pesticide active substances were spiked into the tomato sample. 60 of these active substances were analyzed by LC-MS/MS and 15 by GC-MS/MS device.

\section{Experimental Design}

AGL designed two different media studies. The tomato sample which is found Trifloxystrobin and Imidacloprid pesticide active substances in the 1 st the designed medium was left in the AGL medium. It was then shaken continuously at $37^{\circ} \mathrm{C}$ in a shaking water bath. At the time of release, it was accepted as $0 \mathrm{~min}$, and samples were taken from the medium and analyzed. The same procedures repeated every half hour and $240 \mathrm{~min}$ analyzes continued to be made. In the second medium, some pesticide active substances were spiked to the tomato sample. They were spiked to the tomato sample with a final concentration of $100 \mathrm{ppb}$ and the AGL was added and their behavior towards time was examined. 


\section{Pesticide Residue Analysis in Samples}

The pesticide active substances in the tomato sample were analyzed with Shimadzu GC-MSTQ8040 and Agilent LC-MS/MS-6460 brand devices. Optimization studies were carried out on both the devices using the main stock standards prepared from 222 pesticide standards. The optimum conditions of both devices are given in Tables 1 . analyzes were performed on both devices with 3 replicates of the samples in the vial under the optimum operating conditions and pesticide residues in the samples were determined using the data and library in the device.

Table 1. LC-MS/MS and GC-MS/MS device operating conditions

\begin{tabular}{|c|c|c|c|c|c|c|c|c|}
\hline \multicolumn{5}{|c|}{ LC-MS/MS operating conditions } & \multicolumn{4}{|c|}{ GC-MS/MS operating conditions } \\
\hline \multicolumn{2}{|l|}{ LC-MS/MS } & \multicolumn{3}{|c|}{ Agilent 6460} & \multicolumn{2}{|c|}{ GC-MS/MS } & \multicolumn{2}{|c|}{ Shimadzu TQ 8040 } \\
\hline \multicolumn{2}{|c|}{ Mobile Phase A } & \multicolumn{3}{|c|}{$\begin{array}{l}5 \mathrm{mM} \text { Ammonium format }+\% 0,1 \text { Formic } \\
\text { acid }+1000 \mathrm{~mL} \text { Water }\end{array}$} & \multicolumn{2}{|l|}{ Column } & \multicolumn{2}{|c|}{$\begin{array}{l}\text { Rxi-5SilMS (15 m x } 0.25 \mathrm{~mm} \times 0.25 \\
\text { um) }\end{array}$} \\
\hline \multicolumn{2}{|c|}{ Mobile Phase B } & \multicolumn{3}{|c|}{ Pure methanol } & \multicolumn{2}{|c|}{ Injection Volume } & \multicolumn{2}{|c|}{$2 \mu l$} \\
\hline \multicolumn{2}{|c|}{ Column } & \multicolumn{3}{|c|}{$\begin{array}{l}\text { Poroshell } 120 \text { SB-C18, }(3.0 \times 100 \mathrm{~mm} 2 \\
\text { microns })\end{array}$} & \multicolumn{2}{|c|}{$\begin{array}{l}\text { Pressure } \\
\text { Flow rate }\end{array}$} & \multicolumn{2}{|c|}{$63 \mathrm{kpa}$} \\
\hline \multicolumn{2}{|c|}{ Injection Volume } & \multirow{2}{*}{\multicolumn{3}{|c|}{$2 \mu 1$}} & \multicolumn{2}{|c|}{ Carrier gas } & \multicolumn{2}{|c|}{ Helium } \\
\hline \multirow{2}{*}{\multicolumn{2}{|c|}{$\begin{array}{l}\text { Flow } \\
\text { Run Time }\end{array}$}} & & & & \\
\hline & & $12 \mathrm{~min}$. & & & \multicolumn{4}{|c|}{ The Column Oven $\quad 90^{\circ} \mathrm{C}$} \\
\hline \multicolumn{5}{|c|}{ Pump Gradient Program } & \multirow{2}{*}{\multicolumn{4}{|c|}{$\begin{array}{l}\text { Injection temperature } \quad 250{ }^{\circ} \mathrm{C} \\
\text { Column temperature Program }\end{array}$}} \\
\hline \multirow[b]{2}{*}{ No value } & \multirow{2}{*}{$\begin{array}{l}\text { Time } \\
\text { (min.) }\end{array}$} & \multirow{2}{*}{$\begin{array}{l}\text { \%Mobile } \\
\text { Phase A }\end{array}$} & \multirow{2}{*}{$\begin{array}{l}\text { \%Mobile } \\
\text { Phase B }\end{array}$} & \multirow{2}{*}{$\begin{array}{c}\text { Flow rate } \\
\mathrm{ml} / \mathrm{min}\end{array}$} & & & & \\
\hline & & & & & \multirow{2}{*}{ Start } & \multirow{2}{*}{$\begin{array}{c}\text { Increase speed } \\
(\mathrm{C} / \mathrm{min} .)\end{array}$} & Temperature & Standby time \\
\hline No value & $00: 00$ & 80 & 20 & 0.5 & & & & (min.) \\
\hline No value & $00: 20$ & 80 & 20 & 0.5 & 1 & 0 & 90 & 1 \\
\hline No value & $1: 50$ & 30 & 70 & 0.5 & 2 & 30 & 150 & 0 \\
\hline No value & $6: 00$ & 5 & 95 & 0.5 & 3 & 7 & 200 & 0 \\
\hline No value & $7: 50$ & 5 & 95 & 0.5 & 4 & 15 & 300 & 2 \\
\hline No value & $7: 60$ & 80 & 20 & 0.5 & & & & \\
\hline No value & $11: 00$ & 80 & 20 & 0.5 & & & & \\
\hline No value & $12: 00$ & 80 & 20 & 0.5 & & & & \\
\hline
\end{tabular}

\section{RESULTS AND DISCUSSION}

The properties of Trifloxystrobin and Imidacloprid active substance found in tomato samples are given in table 2 .

Table 2. Properties of Imidacloprid and Trifloxystrobin active substances

\begin{tabular}{cccc}
\hline No & Active Substances & Chemical Class & Molecular Formula \\
\hline $\mathbf{1}$ & Trifloxystrobin & Strobilurin & $\mathrm{C}_{20} \mathrm{H}_{19} \mathrm{~F}_{3} \mathrm{~N}_{2} \mathrm{O}_{4}$ \\
$\mathbf{2}$ & Imidacloprid & Neonicotinoid & $\mathrm{C}_{9} \mathrm{H}_{10} \mathrm{ClN}_{5} \mathrm{O}_{2}$ \\
\hline
\end{tabular}

Türköz et al. in a study did in (2014); Between 2010 and 2012, they made pesticide active substance analysis using 1423 fresh fruit (Apple, grapes, apricot, banana, carrot, cherry, kiwi, lemon, orange, peach, pear, plum, pomegranate, strawberry and tangerine), and vegetable samples (Tomato, eggplant, pepper, cucumber, beans, cabbage, cauliflower, leek, lettuce, mushroom, onion, potato, purslane, arugula, and pumpkin). The most common active substances, they stated that Acetamiprid, Chlorpyriphos, Azoxystrobin, Boscalid, Carbendazim, Imidacloprid, Pyridaben, and Triadimenol (Türköz et al., 2014).

Diop et al. in (2016), in the study of determining pesticide residues in a total of 175 vegetable samples (31 cabbage, 88 lettuce, 57 tomatoes) in four different periods in the Niayes region of Senegal indicated that $65 \%$ of tomato samples $71 \%$ of lettuce samples and $93 \%$ of cabbage samples contained 
one or more pesticide residues. The detected DDT, Dicofol, Chlorpyrifos, Dimethoate and $\lambda$-cyhalothrin pesticide active substances reported that each sample group was dominant at least $35 \%$ (Diop et al., 2016).

Zengin and Karaca, in a study made in (2017); between 2015 and 2016, Turkey's Usak province the pesticide active substance analysis in the 60 piece tomato samples collected in the greenhouse areas was done using LC/MS/MS and GC/MS devices. In the calculation of pesticide residue amount in 25 piece tomato samples collected in 2015; Imidacloprid and Acetamiprid were determined to be between 0.021-0.099 and 0.022-0.078 $\mathrm{mg} \mathrm{kg}^{-1}$, respectively. According to the analysis results of 35 piece tomato samples collected in 2016, the active substances of Trifloxystrobin, Imidacloprid, and Azoxystrobin were determined to be between $0.011,0.015-0.336$ and $0.045-0.061 \mathrm{mg} \mathrm{kg}^{-1}$, respectively (Zengin and Karaca, 2017).

In the 1st medium designed, the results of the AGL medium of pesticide active substances in the tomato sample are given in table 3 .

Table 3. Time-dependent change of pesticide active substance in the tomato sample in AGL.

\begin{tabular}{|c|c|c|}
\hline Time (min.) & Trifloxystrobin $\left(\mathrm{ng} \mathrm{g}^{-1}\right)$ & Imidacloprid $\left(\right.$ ng g $\left.^{-1}\right)$ \\
\hline $\mathbf{0}$ & 83.17 & 10.20 \\
\hline 30 & 75.16 & 10.02 \\
\hline 60 & 57.99 & 10.03 \\
\hline 90 & 54.16 & 10.15 \\
\hline 120 & 43.65 & 10.18 \\
\hline 150 & 37.67 & 10.01 \\
\hline 180 & 32.93 & 10.02 \\
\hline 210 & 32.24 & 10.25 \\
\hline 240 & 24.71 & 10.32 \\
\hline \%Change & 70.29 & $\begin{array}{ll}-1.18 \\
\end{array}$ \\
\hline
\end{tabular}

When the active substances are evaluated according to the above results and chemical properties; While the active substance of trifloxystrobin was $83.18 \mathrm{ng} \mathrm{g}^{-1}$ in $0 \mathrm{~min}$. It decreased in the following times and was determined as $24.71 \mathrm{ng} \mathrm{g}^{-1}$ in $240 \mathrm{~min}$. Change in concentration depending on time was observed as $70.29 \%$. It is possible to talk mention a decrease regularly. These results show that the active substance disappears in time in the AGL medium and turns into another product.

While it was $10.20 \mathrm{ng} \mathrm{g}^{-1}$ at $0 \mathrm{~min}$ for Imidacloprid active substance, it was determined as 10.32 $\mathrm{ng} \mathrm{g}^{-1}$ at 240 min later. It was determined that there was no change between the first concentration and the last concentration depending on the time. These results show that the active substance is not affected by the AGL medium.

The time-dependent change in the AGL medium of 75 pesticide active ingredients spiked to the tomato sample is given in Table 4. 
Table 4. Time-dependent change of spiked pesticide active substances in the AGL medium (ng g${ }^{-1}$ )

\begin{tabular}{|c|c|c|c|c|c|c|c|c|c|c|}
\hline $\begin{array}{c}\begin{array}{c}\text { Active Substances } \\
\left(\mathrm{ng} \mathrm{g}^{-1}\right)\end{array} \\
\end{array}$ & $\begin{array}{c}\mathbf{0} \\
(\mathbf{m i n} .)\end{array}$ & $\begin{array}{c}30 \\
(\text { min. })\end{array}$ & $\begin{array}{c}\mathbf{6 0} \\
\text { (min.) }\end{array}$ & $\begin{array}{c}90 \\
\text { (min.) }\end{array}$ & $\begin{array}{c}120 \\
\text { (min.) }\end{array}$ & $\begin{array}{c}150 \\
(\text { min. })\end{array}$ & $\begin{array}{c}180 \\
\text { (min.) }\end{array}$ & $\begin{array}{c}210 \\
\text { (min.) }\end{array}$ & $\begin{array}{c}240 \\
(\min .)\end{array}$ & $\begin{array}{c}\% \\
\text { Change } \\
\end{array}$ \\
\hline Spiroxamine & 77.58 & 46.43 & 29.44 & 17.17 & 11.71 & 7,78 & 5.35 & 2.95 & 2.42 & 96.88 \\
\hline Diazinon & 66.65 & 50.20 & 26.49 & 19.10 & 14.16 & 9.87 & 7.62 & 3.43 & 3.30 & 95.05 \\
\hline Thiodicarb & 2.04 & 60.63 & 41.94 & 30.78 & 23.84 & 16.15 & 13.3 & 7.99 & 6.65 & 91.90 \\
\hline Chlorsulfuron & 94.13 & 62.14 & 44.21 & 30.41 & 28.6 & 18.55 & 13.84 & 9.42 & 7.97 & 91.54 \\
\hline Thifensulfuronmethyl & 69.79 & 51.02 & 42.12 & 29.64 & 26.39 & 21.27 & 16.24 & 10.14 & 10.38 & 85.12 \\
\hline Sethoxydim & 84.01 & 57.92 & 34.29 & 26.56 & 22.55 & 24.86 & 21.23 & 14.37 & 14.64 & 82.57 \\
\hline Fenazaquin & 85.82 & 74.87 & 48.92 & 36.90 & 38.54 & 31.61 & 25.48 & 16.97 & 15.39 & 82.07 \\
\hline Furathiocarb & 85.40 & 75.66 & 47.60 & 35.29 & 38.89 & 39.69 & 29.15 & 19.51 & 17.11 & 79.97 \\
\hline Triasulfuron & 76.60 & 62.50 & 50.18 & 41.45 & 34.87 & 29.37 & 24.64 & 16.58 & 17.13 & 77.64 \\
\hline Triallate & 118.92 & 84.72 & 68.55 & 51.39 & 30.02 & 59.5 & 49.18 & 33.98 & 32.30 & 72.84 \\
\hline Aldicarb & 99.51 & 87.80 & 66.33 & 58.52 & 53.47 & 38.92 & 38.38 & 33.00 & 30.93 & 68.92 \\
\hline Ethofumesate & 76.63 & 90.10 & 60.02 & 55.66 & 49.94 & 37.89 & 32.55 & 28.01 & 26.14 & 65.89 \\
\hline Butocarboxim & 108.37 & 102.4 & 72.29 & 69.05 & 58.02 & 48.03 & 46.93 & 40.26 & 39.99 & 63.10 \\
\hline Quizalofop-p-ethyl & 114.67 & 107.20 & 71.44 & 54.63 & 44.56 & 72.12 & 57.9 & 43.21 & 42.89 & 62.60 \\
\hline Ethion & 117.15 & 112.02 & 72.64 & 64.36 & 49.14 & 79.71 & 65.84 & 49.27 & 45.76 & 60.94 \\
\hline Tebufenpyrad & 100.56 & 101.51 & 65.04 & 56.46 & 48.64 & 75.1 & 59.02 & 45.72 & 41.84 & 58.40 \\
\hline Methamidophos & 65.52 & 60.80 & 52.34 & 46.34 & 41.21 & 37.56 & 34.44 & 29.54 & 27.36 & 58.24 \\
\hline Tecnazene & 82.27 & 90.23 & 73.66 & 45.08 & 73.44 & 72.34 & 51.95 & 42.53 & 39.08 & 52.50 \\
\hline Quintozene & 80.95 & 95.34 & 68.67 & 50.00 & 70.24 & 71.76 & 56.75 & 45.16 & 39.95 & 50.65 \\
\hline Dicofol & 84.73 & 108.68 & 77.61 & 54.78 & 71.25 & 68.56 & 59.19 & 50.11 & 44.61 & 47.35 \\
\hline Fonofos & 62.72 & 71.38 & 52.00 & 41.27 & 47.95 & 58.65 & 42.76 & 33.75 & 34.43 & 45.11 \\
\hline$\beta$-endosulfan & 81.65 & 107.22 & 66.77 & 60.73 & 70.69 & 63.06 & 61.31 & 59.07 & 45.46 & 44.32 \\
\hline Hexachlorobenzene & 71.95 & 86.42 & 64.43 & 51.52 & 70.37 & 65.35 & 54.11 & 44.69 & 40.37 & 43.89 \\
\hline Pyridate & 59.77 & 38.62 & 33.56 & 45.99 & 44.54 & 54.15 & 46.63 & 38.4 & 34.70 & 41.94 \\
\hline Chlorpyrifos & 82.31 & 105.15 & 72.94 & 61.02 & 78.72 & 75.59 & 65.47 & 56.08 & 47.99 & 41.70 \\
\hline Quinalphos & 91.24 & 96.68 & 76.67 & 61.05 & 63.49 & 78.67 & 61.99 & 52.29 & 53.49 & 41.37 \\
\hline$\alpha$-endosulfan & 78.07 & 102.30 & 67.12 & 57.73 & 72.81 & 68.07 & 61.00 & 54.71 & 45.91 & 41.19 \\
\hline Clodinafop-propargyl ester & 92.6 & 102.00 & 82.17 & 62.32 & 73.32 & 86.72 & 63.48 & 55.75 & 55.95 & 39.58 \\
\hline Tebufenozide & 109.72 & 123.48 & 103.32 & 80.51 & 88.93 & 95.00 & 77.76 & 74.36 & 70.63 & 35.62 \\
\hline Fludioxonil & 88.43 & 106.37 & 91.24 & 62.08 & 96.34 & 93.61 & 71.75 & 68.74 & 58.87 & 33.43 \\
\hline Difenoconazole & 84.53 & 87.94 & 57.48 & 61.20 & 74.52 & 75.39 & 66.80 & 55.42 & 56.35 & 33.34 \\
\hline Triazophos & 100.1 & 100.50 & 91.05 & 77.94 & 91.89 & 87.36 & 72.75 & 72.10 & 68.20 & 31.87 \\
\hline Etofenprox & 104.81 & 47.93 & 45.41 & 86.37 & 75.72 & 95.46 & 91.56 & 75.27 & 72.00 & 31.31 \\
\hline Carboxin & 102.18 & 102.29 & 74.92 & 64.29 & 69.91 & 65.94 & 68.24 & 67.18 & 70.43 & 31.07 \\
\hline 2,4-DDD & 80.27 & 108.38 & 71.07 & 76.35 & 84.07 & 75.13 & 80.04 & 73.68 & 58.04 & 27.69 \\
\hline 4,4-DDD & 79.26 & 106.73 & 69.61 & 74.87 & 82.34 & 74.79 & 79.46 & 72.06 & 57.37 & 27.62 \\
\hline 2,4-DDT & 73.77 & 107.30 & 65.03 & 69.53 & 75.95 & 65.09 & 73.78 & 67.43 & 54.12 & 26.64 \\
\hline Boscalid & 77.86 & 82.72 & 74.74 & 66.97 & 71.98 & 79.44 & 66.73 & 64.48 & 62.94 & 19.15 \\
\hline Penconazole & 83.47 & 88.82 & 72.42 & 74.84 & 72.02 & 78.42 & 72.35 & 69.13 & 72.93 & 12.64 \\
\hline Malathion & 86.12 & 85.28 & 80.46 & 77.16 & 77.96 & 76.07 & 75.19 & 74.93 & 75.67 & 12.13 \\
\hline Hexaconazole & 75.86 & 78.03 & 63.69 & 69.67 & 64.49 & 69.86 & 68.34 & 62.28 & 68.24 & 10.05 \\
\hline Triticonazole & 85.15 & 89.16 & 70.87 & 81.12 & 82.91 & 81.81 & 78.27 & 78.77 & 77.06 & 9.51 \\
\hline Myclobutanil & 69.89 & 72.90 & 63.38 & 63.59 & 65.39 & 69.96 & 65.71 & 64.48 & 63.40 & 9.28 \\
\hline Tetraconazole & 81.77 & 86.04 & 74.33 & 71.54 & 76.45 & 80.97 & 77.71 & 75.26 & 74.20 & 9.26 \\
\hline Molinate & 77.69 & 76.91 & 72.19 & 71.05 & 73.18 & 69.12 & 64.82 & 68.73 & 71.12 & 8.46 \\
\hline Methiocarb & 82.74 & 86.49 & 83.2 & 73.09 & 77.96 & 81.49 & 76.93 & 75.60 & 76.22 & 7.87 \\
\hline Propazine & 95.29 & 97.95 & 89.64 & 90.98 & 87.14 & 89.59 & 88.00 & 86.02 & 89.58 & 5.99 \\
\hline Azoxystrobin & 88.16 & 88.37 & 86.71 & 83.77 & 83.54 & 83.28 & 82.95 & 84.07 & 83.26 & 5.56 \\
\hline Atrazine & 90.61 & 95.02 & 87.55 & 90.21 & 85.07 & 84.21 & 86.69 & 84.27 & 85.73 & 5.39 \\
\hline Triadimenol & 92.36 & 95.84 & 80.55 & 88.88 & 87.65 & 86.09 & 82.52 & 84.62 & 87.46 & 5.30 \\
\hline Terbuthylazine & 85.5 & 86.98 & 78.99 & 82.92 & 78.04 & 79.52 & 77.61 & 76.06 & 81.55 & 4.63 \\
\hline Benalaxyl & 76.64 & 104.76 & 71.58 & 73.64 & 77.13 & 64.91 & 73.31 & 82.77 & 74.38 & 2.95 \\
\hline Ethoprophos & 74.74 & 84.98 & 3.62 & 71.12 & 78.44 & 72.88 & 65.31 & 72.17 & 73.09 & 2.21 \\
\hline Parathion ethyl & 50.71 & 77.65 & 66.6 & 29.12 & 60.22 & 56.87 & 57.35 & 40.83 & 49.61 & 2.17 \\
\hline Alachlor & 89.56 & 87.92 & 80.13 & 91.06 & 85.48 & 87.38 & 82.52 & 82.73 & 88.14 & 1.59 \\
\hline Esfenvalerate & 37.97 & 50.90 & 45.25 & 43.39 & 46.95 & 38.42 & 44.43 & 44.64 & 37.38 & 1.55 \\
\hline Fenvalerate & 59.93 & 89.68 & 65.31 & 64.65 & 67.31 & 50.62 & 65.11 & 78.90 & 59.16 & 1.28 \\
\hline Diphenamid & 87.59 & 87.89 & 82.89 & 83.62 & 81.78 & 86.86 & 80.32 & 86.82 & 86.62 & 1.11 \\
\hline Metolachlor & 44.23 & 48.33 & 42.33 & 43.83 & 43.98 & 44.01 & 42.75 & 41.92 & 44.16 & 0.16 \\
\hline Prochloraz & 91.69 & 97.12 & 71.62 & 88.03 & 79.80 & 86.15 & 86.86 & 80.78 & 91.55 & 0.16 \\
\hline Lenacil & 56.37 & 57.03 & 55.38 & 55.38 & 52.47 & 55.90 & 51.45 & 54.77 & 56.59 & -0.41 \\
\hline Diethofencarb & 82.33 & 88.19 & 80.21 & 75.38 & 80.30 & 82.74 & 77.42 & 78.58 & 82.77 & -0.54 \\
\hline Monolinuron & 84.71 & 83.37 & 80.71 & 77.82 & 78.83 & 79.64 & 77.98 & 82.50 & 85.47 & -0.90 \\
\hline Bupirimate & 79.93 & 84.55 & 75.54 & 80.29 & 74.32 & 76.57 & 76.88 & 79.22 & 80.69 & -0.96 \\
\hline Acetamiprid & 94.43 & 104.34 & 86.07 & 92.76 & 86.01 & 79.59 & 84.94 & 91.01 & 95.63 & -1.27 \\
\hline Heptanaphos & 64.5 & 64.11 & 63.84 & 64.89 & 60.98 & 62.86 & 63.79 & 64.88 & 65.53 & -1.59 \\
\hline Imazalil & 81.77 & 85.04 & 79.86 & 86.14 & 82.43 & 81.69 & 83.03 & 83.11 & 83.08 & -1.60 \\
\hline Dimethoate & 97.52 & 101.19 & 88.78 & 94.61 & 89.73 & 84.01 & 89.26 & 92.87 & 99.10 & -1.63 \\
\hline Omethoate & 89.72 & 94.88 & 81.02 & 90.51 & 90.20 & 77.11 & 85.82 & 77.57 & 91.23 & -1.68 \\
\hline Cymoxanil & 93.38 & 101.74 & 79.94 & 88.40 & 81.42 & 75.66 & 84.26 & 87.43 & 95.02 & -1.76 \\
\hline Prometryn & 91.91 & 93.38 & 88.65 & 95.67 & 89.31 & 90.10 & 90.81 & 96.81 & 94.68 & -3.02 \\
\hline Metalaxyl-M & 78.4 & 76.18 & 78.09 & 79.01 & 76.26 & 74.20 & 78.37 & 85.84 & 81.40 & -3.83 \\
\hline Trichlorfon & 84.93 & 90.82 & 79.56 & 85.51 & 83.22 & 76.75 & 82.27 & 83.81 & 88.28 & -3.94 \\
\hline Paraoxon ethyl & 92.37 & 95.54 & 92.59 & 94.70 & 89.91 & 89.12 & 88.20 & 93.00 & 96.50 & -4.48 \\
\hline Acephate & 68.00 & 69.75 & 73.97 & 70.86 & 69.87 & 72.47 & 71.75 & 70.22 & 71.07 & -4.52 \\
\hline
\end{tabular}


When evaluated according to the above results and chemical properties of 75 pesticides active substance in the AGL medium, for active substances (1-10 units) with a change rate of over 70\% (96.88$72.84 \%$ ), it was determined that there was a statistically decrease in their concentration in time intervals between 0-240 min. When we look at the active substances (11-30 units) which show a change rate below $70 \%$ (68.92-12.13\%); it was observed that there was no statistical decrease time-dependent, but there was a certain thought at different rates between the initial concentration and the final concentration after $240 \mathrm{~min}$. According to the results in the table, 20 (41-60 units) active substance was determined to be almost little of time-dependent change (10.05-0.16\%) between the first and the last concentrations. It was determined that AGL does not affect these active substances. A negative shot (-0,41-4,52) according to 0 min compared 240 min concentrations of 15 (61-75 units) active substances was observed. The AGL was determined to have a positive effect on these active substances.

Table 5. pKa values of pesticide active substances

\begin{tabular}{llc}
\multicolumn{1}{c}{ Active Substances } & \multicolumn{1}{c}{ Chemical Class } & pKa \\
\hline Diazinon & Organophosphorus & 2.60 \\
Chlorsulfuron & Sulfonylurea & 3.40 \\
Thifensulfuronmethyl & Triazinylsulfonylurea & 4.00 \\
Sethoxydim & Cyclohexanedionedioxime & 4.40 \\
Triasulfuron & Triazinylsulfonylurea & 4.64 \\
Penconazole & Triazole & 1.51 \\
Tetraconazole & Triazole & 0.80 \\
Propazine & Triazine & 1.70 \\
Atrazine & Triazine & 1.60 \\
Terbuthylazine & Triazine & 2.00 \\
Prochloraz & Midazole & 3.80 \\
Lenacil & Uracil & 10.70 \\
Bupirimate & Pyrimidinol & 5.00 \\
Acetamiprid & Eonicotinoid & 0.70 \\
Imazalil & Imidazole & 6.49 \\
Cymoxanil & - & 9.70 \\
Prometryn & Triazine & 4.10 \\
Acephate & Organophosphorous & 8.35 \\
\hline
\end{tabular}

It was observed that organophosphorus pesticides reacted differently from the high rate of change to a low rate of change in the time-dependent AGL medium. Although active substances are in the same chemical class and behave differently; they were determined that the pKa values of the active substances differ solubilities in water, the type and number of atoms it contains, of the molecular formula, of the bond structure between atoms, whether it contains a ring structure.

In the AGL medium of carbamate pesticide groups generally highly was dissolved and turned into other products and was determined that carbamate pesticides bound to N-phenyl and N-methyl were not affected by the AGL medium.

Organochlorinated pesticides were determined to vary between $50-25 \%$ in the AGL medium. It was determined that pesticides with Trizalo and Triazine groups were generally not affected by the AGL medium. When looking at other groups (Imidazole, Uracil, Pyrethroid, Strobilurin) pesticides, the change rates chemical structure, water-solubility, pKa values, bond structure, etc., it was observed that it changed depending on the reasons.

Zawiyah et al. in a study did in (2007); they had been examined Organochlorine and Pyrethroid group pesticide residues in fruit and vegetable samples collected from the markets in Malaysia. It determined the active substance of Cypermethrin as an average of $0.47 \mathrm{mg} \mathrm{kg}^{-1}$ in 38 of 302 vegetable 
samples. They stated that the active substance found was between $0.16-1.48 \mathrm{mg} \mathrm{kg}^{-1}$ in tomato, paprika, bean, bell pepper, and local products (Zawiyah et al., 2007).

When evaluated according to $\mathrm{pKa}$ values, it was determined that the active substances with small pKa values dissolved more and turned into another structure, and the active substances with large pKa values were not affected by the medium.

According to the above all evaluations, it was determined that the active substances in different classes behave differently, carbamate pesticides dissolve better in the AGL medium, organochlorinated pesticides dissolve less than according to carbamate pesticides, organophosphorus pesticides give react differently, and the trizalo and triazine group pesticides are not affected by the medium. In general, the effect of AGL on pesticides was determined that the chemical structure of the active substance, its water solubility, pKa values, open formula structure, whether it was the ring structure and, have changed as time-dependent.

\section{CONCLUSION}

In the study carried out in AGL medium, in the analysis made for a total of 240 min every half hour of tomato sample containing pesticide active substance was observed that the active substance of Trifloxystrobin changed against time. The change in Imidacloprid active substance could not be observed. It was determined that the effect of the AGL is different for each active substance. According to the results of the study carried out with 75 active substances spiked to the tomato sample in the AGL medium; depending on time, change in the concentration of a large part of active substances was observed. It was determined that the concentrations of some pesticide active substance were not affected at all. The water solubility, polarity, $\mathrm{pKa}$ values, closed and open formulas of the pesticide class were determined to be effective in this medium. It is thought that detailed studies should be done about what the active substances turn into.

\section{Conflict of Interest}

The article authors declare that there is no conflict of interest between them.

\section{Author's Contilbutions}

The authors declare that they have contributed equally to the article.

\section{REFERENCES}

Algharibeh GR, AlFararjeh MS, 2019. Pesticide residues in fruits and vegetables in Jordan using liquid chromatography/tandem mass spectrometry. Food Additives and Contaminants: Part B Surveillance, 12: 65-73. https://doi.org/10.1080/19393210.2018.1548505

An X, Wu S, Guan W, Lv L, Liu X, Zhang W, Cai L, 2018. Effects of different protective clothing for reducing body exposure to chlorothalonil during application in cucumber greenhouses. Human and Ecological Risk Assessment, 24: 14-25. https://doi.org/10.1080/10807039.2017.1349540

Arias N, Arazuri S, Jarén C, 2013. Ability of NIRS technology to determine pesticides in liquid samples at maximum residue levels. Pest Management Science, 69: 471-477. https://doi.org/10.1002/ps.3392

Calvo H, Redondo D, Remón S, Venturini ME, Arias E, 2019. Efficacy of electrolyzed water, chlorine dioxide and photocatalysis for disinfection and removal of pesticide residues from stone fruit. $\begin{array}{lllll}\text { Postharvest Biology } & \text { and } & \text { Technology, }\end{array}$ https://doi.org/10.1016/j.postharvbio.2018.10.009

Diop A, Diop YM, Thiaré DD, Cazierc F, Sarra OS, Kasprowiake A, Landy D, Delattre F, 2016. Monitoring survey of the use patterns and pesticide residues on vegetables in the Niayeszone, Senegal. Chemosphere, 144: 1715-1721. 
Elmastas A, 2018. Yaş meyve sebze ürünlerinin çeşitli koşullarda pestisit kalıntılarının LC-MS/MS ve GC-MS/MS ile analizlerinin kantitatif tayini, Dicle Üniversitesi Fen Bilimleri Enstitüsü, Doktora Tezi (Basılmış).

Farajzadeh MA, Sohrabi H, Mohebbi A, 2019. Combination of modified QuEChERS extraction method and dispersive liquid-liquid microextraction as an efficient sample preparation approach for extraction and preconcentration of pesticides from fruit and vegetable samples. Food Analytical Methods, 12: 534-543. https://doi.org/10.1007/s12161-018-1384-X

Farajzadeh, MA, Sohrabi H, Mohebbi A, Mogaddam MRA, 2019. Combination of a modified quick, easy, cheap, efficient, rugged, and safe extraction method with a deep eutectic solvent based microwave-assisted dispersive liquid-liquid microextraction: Application in extraction and preconcentration of multiclass pestic. Journal of Separation Science, 42: 1273-1280. https://doi.org/10.1002/jssc.201801107

Galia E, Nicolaides E, Hörter D, Löbenberg R, Reppas C, Dressman JB, 1998. Evaluation of various dissolution media for predicting in vivo performance of class I and II drugs. Pharmaceutical Research, 15: 698-705.

Hou J, Zhang Q, Zhou Y, Ahammed GJ, Zhou Y, Yu J, Xia X, 2018. Glutaredoxin GRXS16 mediates brassinosteroid-induced apoplastic $\mathrm{H}_{2} \mathrm{O}_{2}$ production to promote pesticide metabolism in tomato. Environmental Pollution, 240: 227-234. https://doi.org/10.1016/j.envpol.2018.04.120

Jara EA, Winter CK, 2019. Safety levels for organophosphate pesticide residues on fruits, vegetables, and nuts. International Journal of Food Contamination, 6: 2-8. https://doi.org/10.1186/s40550019-0076-7

Kapsi M, Tsoutsi C, Paschalidou A, Albanis T, 2019. Environmental monitoring and risk assessment of pesticide residues in surface waters of the Louros River (N.W. Greece). Science of the Total Environment, 650: 2188-2198. https://doi.org/10.1016/j.scitotenv.2018.09.185

Lehotay SJ, 2019. Possibilities and limitations of isocratic fast liquid chromatography-tandem mass spectrometry analysis of pesticide residues in fruits and vegetables. Chromatographia, 82: 235250. https://doi.org/10.1007/s10337-018-3595-0

Ersoy N, Tekinarslan O, Akcay E, Ulas O, 2019. Determination of pesticide residues in apricot (Prunus armeniaca L.) grown determination of pesticide residues in apricot (Prunus armeniaca L.) grown at good agricultural practices (GAPs) by LC-MS/MS and GC-MS. Erwerbs-Obstbau, 60: 49-358. https://doi.org/10.1007/s10341-018-0383-9

Song NE, Lee JY, Mansur AR, Jang HW, Lim MC, Lee Y, Nam TG, 2019. Determination of 60 pesticides in hen eggs using the QuEChERS procedure followed by LC-MS/MS and GC-MS/MS. Food Chemistry, 298: 125050. https://doi.org/10.1016/j.foodchem.2019.125050

Türkoz Bakırcı G, Yaman Acay DB, Bakırcı F, Ötleş S 2014. Pesticide residues in fruits and vegetables from the aegean region. Turkey Food Chemistry, 160: 379-392.

Wei J, Chen Y, Tiemur A, Wang J, Wu B, 2018. Degradation of pesticide residues by gaseous chlorine dioxide on table grapes. Postharvest Biology and Technology, 137: 142-148. https://doi.org/10.1016/j.postharvbio.2017.12.001

Wu ML, Wu YC, Chen YC, 2019. Detection of pesticide residues on intact tomatoes by carbon fiber ionization mass spectrometry. Analytical and Bioanalytical Chemistry, 411: 1095-1105. https://doi.org/10.1007/s00216-018-1539-z

Zawiyah S, Che Man YB, Nazimah SAH, Chin CK, Tsukamoto I, Hamanyza AH, Norhaizan I, 2007. Determination of organo chlorine and pyrethroid pesticides in fruitand vegetables using SAX/PSA clean-upcolumn. Food Chemistry, 102: 98-103.

Zengin E, Karaca İ, 2017. Uşak ilinde örtü altı üretimi yapılan domateslerdeki pestisit kalıntılarının belirlenmesi. Süleyman Demirel Üniversitesi Fen Bilimleri Enstitüsü Dergisi, 21: 554-559. 